\title{
School Leadership Effectiveness and Students' Academic Achievement in Secondary Schools of Guraghe Zone SNNPR
}

\author{
Etecha Fekadu Dabesa', Shireye Fekadu Cheramlak² \\ ${ }^{I}$ Department of Educational Planning and Management, College of Education and Behavioral \\ Studies, Wolkite University, Wolkite, Ethiopia. \\ ${ }^{2}$ Department of Educational Planning and Management, College of Education and Behavioral \\ Studies, Wolkite University, Wolkite, Ethiopia
}

\begin{tabular}{|c|c|}
\hline Article Info & Abstract \\
\hline $\begin{array}{l}\text { Article history: } \\
\text { Received: } 09 \text { December } 2020 \\
\text { Revised: } 28 \text { March } 2021\end{array}$ & $\begin{array}{l}\text { Purpose: The main purpose of this study was to assess the school leadership } \\
\text { effectiveness and students' academic achievement in government secondary } \\
\text { schools' of Guraghe Zone, SNNPR, Ethiopia. }\end{array}$ \\
\hline Accepted: 05 April 2021 & $\begin{array}{l}\text { Methodology/Approach/Design: Co-relational research design and a } \\
\text { quantitative research method were employed. The sample size included } 225\end{array}$ \\
\hline $\begin{array}{l}\text { Keywords: } \\
\text { Leadership Effectiveness, } \\
\text { Achievement, } \\
\text { School Principal, } \\
\text { School Administration }\end{array}$ & $\begin{array}{l}\text { secondary school teachers, principals, head departments and } 2298 \text { students' } \\
\text { grade ten national examination results from } 10 \text { public secondary schools. } \\
\text { Both primary and secondary data were used for this study. } \\
\text { Results: The results showed that there is a positive and significant } \\
\text { relationship between Leadership effectiveness and students' academic } \\
\text { achievement }\left(r=.653^{*}, p<.0 .041\right) \text {. The participants indicated that setting a }\end{array}$ \\
\hline Paper Type : & $\begin{array}{l}\text { clear school vision, promoting professional practice, developing a } \\
\text { mechanism for teachers to share their experience impact students' academic }\end{array}$ \\
\hline Research Article & $\begin{array}{l}\text { achievement. Moreover, the results showed that the principal's effectiveness } \\
\text { involves the teaching staff and enhances student achievement. Furthermore, }\end{array}$ \\
\hline Corresponding Author: & $\begin{array}{l}\text { the study indicated that there were positive and significant relationships } \\
\left(r=.653^{*}, p<.0 .041\right) \text { in the mean academic achievement among the sampled }\end{array}$ \\
\hline EtechaFekadu Dab & $\begin{array}{l}\text { secondary school and the two years CGPA of } 2009-2010 E . C . Q \\
\text { Practical Implications: The findings might have practical implications for }\end{array}$ \\
\hline Email: & $\begin{array}{l}\text { concerned authorities. Schools and teachers should apply the } \\
\text { recommendations of the study to bring improvement in students }\end{array}$ \\
\hline feka & $\begin{array}{l}\text { Originality/Value: There was an association with a significant relationship } \\
\text { that existed between school leadership effectiveness and students' academic } \\
\text { achievement. Moreover, the focus should be on the development of qualified } \\
\text { and experienced teachers with strong school leadership effectiveness abilities } \\
\text { to improve learning and students' achievement. }\end{array}$ \\
\hline
\end{tabular}

1. Introduction

School leadership has become a priority in education policy agendas in a global context. It plays a great role in improving school outcomes by influencing the motivation of teachers, parents, community, and stakeholders in education (Nusche\& Moorman, 2008). School Leadership can be understood as a process of influence based on clear values and beliefs and leading to a "vision" for the school. The vision is articulated by leaders who seek to gain the commitment of staff and stakeholders to the ideal of a better future for the school, its learners and stakeholders (Bush, 2007). 
Leadership effectiveness is believed to be crucial for the overall success of any organization. Accordingly, Oakland, (1993) asserts that effective leadership is an approach to improve the competitiveness, effectiveness and flexibility of the whole organization through planning, organizing and allowing participation of all members at the appropriate level. Effectiveness is defined in different ways. However, as to Drucker (2011), the effectiveness perspective is concerned with whether things are continuing to be appropriate, particularly in the context of a rapidly and increasingly demanding external environment.

The school principal is considered to be a person in leadership, leadership is a concept both multidimensional and all-round where "the values, goals, beliefs, and decision-making-skills of the principal give purpose and meaning to the policies and procedures which he/she is duty bounded to implement" (Goddard,2003, p.13). Schools prepare students for the future; teach them the skills they need to be successful in life; and motivate them to read, write and think creatively. School leadership has various roles. They are responsible for the overall operation of their schools. They set school goals, conducting classroom observations, assessing learning materials, evaluate teachers, and communicating with other school communities. In supporting this idea, the BLS (2010) noted that the major roles of school principals are: they set academic tone and work actively with teachers to develop and maintain high curriculum standards, formulate mission statement and establish performance goals and objectives.

The rapid growth of educational institutions and the ever-increasing enrollment will require improved management. With the increase in the number and size of many secondary schools; employment of more teachers, changes in school structure, and enlarged curriculum, and the problems of effective leadership by school principals could become more complex (MoE, 2006). Rapid expansion through the creation of secondary schools means that more teachers may be recruited as leaders. Some of these school leaders may have less experience, as experienced principals are no longer available for some schools. It is well known that school leadership is one of the most important factors contributing to the success of the school (MoE, 2006).

As secondary schools are a place where students prepare themselves to join their further education in Universities, Colleges, Technical and Vocational training, the school should work hard to realize this objective through collaborative efforts of stakeholders. On this issue, Conley (2007) suggests that high schools and teachers must set college-ready expectations for students; teach rigorous content so that students can apply knowledge in new situations. The main education challenges that Guraghe zone has been facing for many years are related to quality education in the performance of Ethiopian General Secondary Education Certificate and university entrance examination result (The Annual Report of Guraghe zone education office 2006 E.C). As indicated in GEQIP (2010), the main target of school improvement is to advance students' learning and to enhance students' academic achievement. Therefore, to make school leadership effective, the ministry of education has been working steadily to ensure the inclusion of school improvement programs (SIP) in different schools. For example: In the zone, there is a school grant budget for school improvement programs even 
though schools are investing this budget on school infrastructure fulfillment than on student achievement improvement.

Thakur (2004) stated that secondary school leadership is a major determining factor in the quality of education and school performance. Leadership is essential in improving school management and raising standards of education. The quality of education depends on the nature of leadership provided by the school principal, his or her ability to control, direct and guide teachers and students. The quality of leadership also plays a vital role in students' academic achievement as it is concerned with teachers, pupils, rules, regulations, and policies that govern the school (Buhere, 2007).

Recent policy discussions in the United States of America and elsewhere suggest there is broad support for expanding teachers' participation in leadership and decision-making tasks besides the principals. These discussions are supported by research suggesting that increased teacher participation in schools has the potential for significant positive effects on school improvement including students' academic achievement (Huber, 2004; Leithwood\& Beatty, 2007; Leithwood et al., 2008; Matthews \& Sammons, 2005). Studies on leadership have focused on principals when it should be on the classroom teachers. Teachers play a key role in the delivery of quality instruction. Their responsibilities include ensuring educational strategies are in place that supports effective learning for all students (Wango, 2009). They serve as a facilitator, guide, and provider of quality instruction (Bakhda, 2006). Good subject teachers understand that quality school principles/ are essential for improving students' academic achievement.

Among the major persistent education-related challenges that Ethiopia has been facing, over the years, is the issue of quality education. Following the formulation of the Education and Training Policy (MOE, 1994), the Ethiopian government has taken different measures to alleviate those educational problems and remarkable changes have been exhibited in education expansion. According to the Ministry of Education (MoE, 2010), the efforts made to strengthen the professional skills of school leaders' effectiveness and the student academic achievement which has been in place is part of the endeavor to look for the solutions to education quality problems. The researcher argues that effective leadership practices of school principals play a great role in making school effective, ( Bush, 2008) as emphasizes the quality of school principal's leadership has a positive effect to improve student's academic achievement and to make school effective.

According to Day \& Sammons (2009) described that school principals carry the leadership activities through practicing their knowledge and the required skills to influence followers to achieve common goals. Therefore, school principals are expected to improve the overall school performance and student achievement through effective school leadership practices. To be an effective leader, school principals need to have better knowledge and the required skills of more than one leadership theory to serve their customers effectively and efficiently. Additionally, when school principals have adequate knowledge and skill on school leadership they can choose which leadership theory, model, or style is appropriate to their environment. Moreover, as the major notion of leadership is to influence followers, school leaders should 
develop the skill of influencing others and the ability of engaging stakeholders to achieve common objectives. Thus, the researcher is motivated to assess school leadership effectiveness and students' academic achievement in government secondary schools of Guraghe zone, SNNPR State.

Leadership has today become a very complex phenomenon because of the complexity of globalization, industrial, social or political organization and technological advancement especially in information technology (Ibukun, Oyewole, \& Abe, 2011). Effective Leadership may play a key role in improving educational processes and, potentially, in enhancing student academic achievement, Secondary education is the basic requirement for selection into tertiary institutions and further skills training (MOE, 1994).

The new education and training policy applied in Ethiopia in recent years has addressed a number of issues of which the introduction of standardized students' achievement. Concerning this point, there seems a gap between what ought to be and what exists, in reality, to bring in the intended outcomes of the students' academic achievement that could be because of different factors. Factors of students' achievement can be investigated in terms of variables which is the school leaders' effectiveness. One of the most obvious aspects that influence students' academic achievement is the school leaders. Despite all the efforts made the question of whether school leaders' can impact the students' academic achievement is still not figured out.

Some studies claim that school leaders' can contribute a significant positive impact, be it direct or indirect and student academic achievement in particular (Branch et al., 2013; Louis et al., 2010). Long ago, others argued that the effectiveness of school leaders' in contributing to students' achievement remains a topic of debate that is yet to be resolved (Firestone and Herriott, 1982; Grift, 1990; Rowan et al., 1982). Cuban (1988) links leadership with change. Leadership takes many forms but certainly depends greatly on the context of each school, teachers, students and community.

In Ethiopia, many research were conducted for instance Aklilu (2011) studied on assessment of "instructional leadership practice in the secondary school of Sheka Zone" found out that instructional leaders do not possess the necessary knowledge and skills that help them in leading the school community as they were all subject specialist. But he did not focus on the relation of leadership effectiveness and students' academic achievement.

In addition to this, Dessalegn et al. (2016) also conducted their study on the relationship between secondary school principals' leadership effectiveness as perceived by secondary school teachers and students' academic achievement in West Hararghe Zone, Oromia Regional State, Ethiopia. The study finding showed that there was no significant correlation between a school principal's leadership effectiveness and students' academic achievement. The study focused not only on the relation of leadership effectiveness and students' academic achievement. Rather, it addressed teachers' perception of principal leadership effectiveness. 
Furthermore, Tadesse (2011)explored the effectiveness of Principals in HadiyaZone and it was revealed that that socio-economic background, principal personal trait, job assignment, luck of openness were taken as the major finding of the study. Alemayehu (2011) found out that the focus of the principals in their leadership activities was not in academic activities, as much of their time was spent on administrative tasks. In addition, Mekuanint (2012) in his assessment of "Principals Leadership style of Public Secondary schools of Jimma Zone" found out that the most prevalent leadership style is low directive and high supportive behavior which may not be appropriate to all situations.

In his study, Teshale (2014) concluded that teachers' motivation, school culture, vision, mission and goal statements, teachers' status and power-sharing were major findings of leadership effectiveness. The most recent research was conducted by Daniel Sorato, (2018) in which he examined the school leadership practices of principals of secondary schools in the area Kembata Tembaro Zone (SNNPR). The study finding revealed that poor competence of principals, lack of training and experience sharing programs, poor school-community relationship, role diversity, lack of appropriate supervisory support, and scarcity of educational resources hinder principals' effectiveness.

In general, the above listed six studies assessed the leadership styles, practices and problems of educational leadership in secondary schools of different areas of the country and the study conducted in West Hararghe also focused on teacher's perception of principal leadership effectiveness and students' academic achievement. But this study is different from them in that it aimed at assessing the effectiveness and contributions of school leadership for the improvement of students' academic achievement at the secondary school of Guraghe zone. Moreover, the previous researchers did not include some other factors (determinants) of school leadership effectiveness further and prioritize some basic fulfilments to enhance school leaders' effectiveness. Thus, the researcher believes that the existing gap of the study site is considered to be filled through this study.

Hence, based on the identified research gap, the researcher aspired and carried out this study to tie with the school leadership effectiveness and its influence on students' academic achievement. Therefore, the purpose of this study is to examine the effectiveness of school leadership at Guraghe Zone secondary schools and identify whether the principal's leadership effectiveness can significantly influence the students' academic achievement in the secondary schools atGuraghe Zone in SNNPR, Ethiopia. The study is significant as it provides valuable analyzed data for concerned bodies, particularly for woreda education office, Regional Education Bureau and Zonal Education Department.

\section{Methodology and Procedures}

\section{Scope of the Study}

To make the study more manageable, the study was delimited to the investigation of school leadership effectiveness on students' academic achievement in selected secondary schools of Guraghe zone, SNNP region. Conducting a study in all secondary schools of the zone would be advantageous to have a complete picture of the effectiveness of school leaders on 
academic achievement on the students' grade 10 national examinations. However, due to time and finance constraints, the study was delimited to five sample woredas and ten (10) selected secondary schools of the zone. The study was also considered two consecutive years of national examination achievements (from 2009 to 2010) that were taken by grade 10students' in the study area. Furthermore, the study was conducted from December 2019 to June 2019.

\section{Research Design}

To undertake this study, a specifically correlational research design was employed. Correlation design is a measure of the relationship or association between two continuous numeric variables (Orodho, 2009). Correlation analysis results give a correlation coefficient which measures the linear association between two variables (Crossman, 2013).

According to Creswell (2012), a basic rationale for this design is that one data collection form supplies strengths to offset the weaknesses of the other form and that a more complete understanding of a research problem results from collecting both quantitative and qualitative data. To realize this objective of the study, a correlational design was utilized to conduct study. Data would be analyzed in a correlational design that allowed for the examination of relationships among variables (Gay\&Airasian 2006).

\section{Research Method}

The quantitative research approach was employed in the study with more emphasis on the quantitative method as the leading method through close-ended and open-ended questions. A quantitative approach was emphasized because investigating the relationship between school leadership effectiveness and students' academic achievement using correlation research study design to examine the relation between the two variables in selected government secondary schools at Guraghe zone could better understand by collecting large quantitative data. To this end, the qualitative approach is incorporated in the study to validate and triangulate the quantitative data.

\section{Sources of Data}

To obtain reliable data about the relationship between school leadership effectiveness and students' academic achievement under the study locality, the researchers used both primary and secondary sources of data for this study.

\section{Primary Sources}

Primary data were gathered from zonal education experts, woreda education experts, school principals, teachers and head departments of secondary schools at Guraghe Zone.

\section{Secondary Sources}

Data was also gathered from document analysis, records written in the Ethiopian General Secondary Education Certificate (EGSECE) from school level document and minutes concerning issues discussed and decided by leadership in the school in relation to students' academic achievements. 


\section{Sample size and Sampling Technique}

A study population is the entire group of people to which a researcher intends the results of a study to apply. These were the ones a researcher wishes to generalize the results of the research study (Borg \&Gall, 1989). There are 13woredas and 89 secondary schools and 2526 teachers in Guraghe Zone. For this study, the researcher selected five 5(38.46\%) woredas namely, Muher Aklile, Edja, Cheha, Abeshga, and Enmorenaener to be included in the study by assuming they were representative of thirteen woredas from Guraghe Zone. The target population of this study is 225 including school principals, head departments, teachers and 2298 students for document analysis from government secondary schools.

These five woredas have 22 secondary schools from which the researcher selected 10(ten schools) (45\%) by using simple random sampling to get a good representative sample. This is because it gives equal chances for selecting these secondary schools and the selection of the others does not affect the chance of the others to be selected (Teddlile and Yu, cited in Furi, 2016). Accordingly, Aklile, Teklehymanot, Kotergedera, Agena, Yewahny, Dakuna, Gurda, Holle, Gunchera and Gazanch secondary schools were selected.

Regarding the sample size of respondents, the researchers' election was based on the idea of Creswell (2012) that indicates a general rule of thumb is to select as large a sample as possible from the population. i.e., the larger the sample, the less the potential error. So that in this study because of a total number of students 2298 for document analysis and teachers are 215, and principals 10, the researchers selected all Principals 10(100\%), teachers, and head departments $140(65 \%)$ by using the idea of Yamane (1967:886) formula, principals by using Census sampling techniques due to their small number and manageability.

The following table presents the total number of teachers in the sampled schools and the sample size of teachers who were involved in the study from each school.

$$
n=\frac{N}{1+N\left(e^{2}\right)}
$$

Where: $\mathrm{n}=$ required the sample size

$\mathrm{N}=$ the study population

$\mathrm{e}=$ the level of precision $(0.05)$

$1=$ designates the probability of the event occurring

Therefore: $\boldsymbol{n}=\frac{\mathbf{2 1 5}}{\mathbf{1 + 2 1 5}(0.05)^{2}}=\mathbf{1 4 0}$

After determined the sample size and the proportional sample size from each stratum was calculated by using the following formula:

$$
\mathrm{ni}=(\mathrm{n} \times \mathrm{Ni}) / \mathrm{N}
$$

Where: $n i=$ sample size for respondents

$\mathrm{n}=$ the total number of selected for each secondary schools

$\mathrm{Ni}=$ the total sample size for each selected secondary schools

$\mathrm{N}=$ the total number of secondary schools 
Therefore, the distribution of the sampling technique and sample size in relation to their respective population for each of the 10 secondary schools in GuragheZone is precisely summarized in table1.

Table 1: Sample and sample size to be taken from each selected schools

\begin{tabular}{|c|c|c|c|c|c|c|}
\hline $\begin{array}{l}\text { Samples } \\
\text { Woredas }\end{array}$ & \multirow[t]{2}{*}{$\begin{array}{l}\text { Sample } \\
\text { secondary } \\
\text { schools }\end{array}$} & \multirow{2}{*}{$\begin{array}{l}\text { Samples } \\
\text { Principals }\end{array}$} & \multirow{2}{*}{$\begin{array}{l}\text { Target } \\
\text { Population } \\
\mathbf{N} \\
1\end{array}$} & $\begin{array}{l}\text { Sample } \\
\text { Size } \\
\frac{n * N 1}{N}\end{array}$ & \multirow{2}{*}{$\begin{array}{c}\% \\
100\end{array}$} & \multirow{2}{*}{$\begin{array}{l}\begin{array}{l}\text { Sampling } \\
\text { techniques }\end{array} \\
\text { Census }\end{array}$} \\
\hline & & & & 1 & & \\
\hline & Kotergedera & Teachers & 25 & 16 & 64 & Proportional \\
\hline \multirow[t]{5}{*}{ 1. Edja } & & Principals & 1 & 1 & 100 & Census \\
\hline & Agena & Teachers & 13 & 8 & 62 & Proportional \\
\hline & & Principals & 1 & 1 & 100 & Census \\
\hline & Yewahny & Teachers & 25 & 16 & 64 & Proportional \\
\hline & & Principals & 1 & 1 & 100 & Census \\
\hline \multirow{4}{*}{ 2.Muher Aklile } & Aklile & Teachers & 18 & 12 & 67 & Proportional \\
\hline & & Principals & 1 & 1 & 100 & Census \\
\hline & Teklehymanot & Teachers & 23 & 15 & 65 & Proportional \\
\hline & & Principals & 1 & 1 & 100 & Census \\
\hline \multirow[t]{5}{*}{ 1. Cheha } & Dakuna & Teachers & 28 & 18 & 64 & Proportional \\
\hline & & Principals & 1 & 1 & 100 & Census \\
\hline & Gurda & Teachers & 24 & 16 & 67 & Proportional \\
\hline & & Principals & 1 & 1 & 100 & Census \\
\hline & Gunchera & Teachers & 20 & 13 & 65 & Proportional \\
\hline \multirow{3}{*}{$\begin{array}{l}\text { 2. Enmorenaen } \\
\text { er }\end{array}$} & & Principals & 1 & 1 & 100 & Census \\
\hline & Gazanch & Teachers & 21 & 14 & 67 & Proportional \\
\hline & & Principals & 1 & 1 & 100 & Census \\
\hline \multirow[t]{2}{*}{ 3. Abeshga } & Holle & Teachers & 18 & 12 & 67 & Proportional \\
\hline & & Principals & 10 & 10 & 100 & Census \\
\hline Total & & Teachers & 215 & 140 & 65 & Proportional \\
\hline
\end{tabular}

Source: Guraghe zone education Department EMIS / 2019

\section{Data Gathering Tools}

Using different types of tools for gathering data help get adequate and sufficient data for the problem under study. In supporting this idea, John (2010) emphasizes that employing multiple methods of data collection helps the researcher combine the strength and amend some of the inadequacies when only one method is used independently. Therefore, the 
researcher used three different types of data gathering instruments in this study. These were questionnaires, interviews, and documents review.

\section{Questionnaire}

The main reason to use a questionnaire was for obtaining factual information, opinions and attitudes from a large number of subjects within a short period. Based on Kumar's (1999) advice, the choice of instrument to collect primary data is mainly determined by the purpose of the study, the resource available and the skills of the researcher. The questionnaire was constructed, validated, and then distributed to school principals, teachers' head department. Questionnaires included both ten open and thirty-five closed-ended items respectively.

\section{Interview}

The interview permits greater depth of response which is not possible through any other research data collection means (Abebayehu et al., 2011). A well-constructed and semistructured interview was prepared and administrated to heads of departments because they are believed to have sufficient information on the topic under study as they are practicing day-today school leadership effectiveness.

\section{Document Analyses}

Document analysis was made on the previous records, and it was one of the data collection tools that were used to validate or identify the consistency of questionnaire responses with the respondents included students' academic achievements document in the study. It focused on records and minutes that show the students' academic achievements result and checklists of the schools leadership used to influence the achievement of students. According to Abiyi et al., (2009) document analysis can give an expert understanding of the available data, and also it is cheap.

\section{Methods of Data Analysis}

Both descriptive and inferential statistics used to analyze the data. In general, to analyze the data, the researchers have used descriptive statistics, figures, correlation and ordinary least square. Descriptive statistics were used to describe the data, while inferential statistics were used to generalize the data finding (Kimberly, 2011). In agreement with the data that were collected from respondents, the close-ended items were systematically coded, tabulated and organized for analysis. The organized and coded data were stored in an editable excel spreadsheet and imported to SPSS version 20 and analyzed using such descriptive statistics as a percentage, frequency, mean standard deviation and average mean; and inferential statistics correlation, the significance of school leadership effectiveness as it relates to students' academic achievements.

Even though five-point Likert scales at a significance level of 0.05 at various levels of rating scales (Very low, low, moderate, high, and very high,) were used to collect data from respondents, to make analysis clear, the responses were analyzed with mean value 1.49 as very low, 1.50-2.49 as low, 2.50-3.49 as Moderate, 3.51-4.49 as high and4.5-5as in implementation of the items. For the sake of analyses, very high and high indicate effective implementation of each item, and moderate presents neither positive nor negative agreement 
and similarly very low and low indicate ineffective implementation of items in the schools (Desalegn, 2014).

Finally, the above methods of data analysis, data obtained through an interview, open-ended questions, and document review were analyzed and interpreted qualitatively by describing or narrating the responses provided by the respondents.

\section{Results and Discussion}

Analysis and discussion were made by using the data gathered from principals, head departments, teachers, and student's document of secondary schools of Guraghe Zone.

Similar questionnaires were distributed to teachers and principals, as well as interviews for head departments. One hundred and fifty (150) questionnaires were distributed to respondents and interestingly 147 similar Questionnaires were properly filled in and returned. To validate the data from questionnaire were conducted with teachers and principals. Documents were also reviewed to student's results as supplementary data collecting tools. The data gathered through questionnaires were tallied, tabulated and quantified.

\begin{tabular}{|c|c|c|c|c|c|}
\hline No & Name of school & $\begin{array}{l}\text { Number of } \\
\text { distributed }\end{array}$ & $\begin{array}{l}\text { Number } \quad \text { of } \\
\text { Reponses }\end{array}$ & Reponses rate in \% & $\begin{array}{l}\text { Number of students from } \\
\text { sample school }\end{array}$ \\
\hline \multirow[t]{2}{*}{1} & Kotergedera & 17 & 17 & $100 \%$ & \\
\hline & & & & & 278 \\
\hline 2 & Agena & 9 & 9 & $100 \%$ & 118 \\
\hline 3 & Yewahny & 17 & 16 & $94.1 \%$ & 247 \\
\hline 4 & Aklile & 13 & 13 & $100 \%$ & 254 \\
\hline 5 & Teklehymanot & 16 & 16 & $100 \%$ & 420 \\
\hline 6 & Dakuna & 19 & 18 & $94.7 \%$ & 470 \\
\hline 7 & Gurda & 17 & 17 & $100 \%$ & 117 \\
\hline 8 & Gunchera & 14 & 14 & $100 \%$ & 199 \\
\hline 9 & Gazanch & 15 & 15 & $100 \%$ & 85 \\
\hline 10 & Holle & 13 & 12 & $92.3 \%$ & 110 \\
\hline Total & & 150 & 147 & $98 \%$ & 2298 \\
\hline
\end{tabular}

A total of 35 items were prepared and distributed to 150 respondents. From these 140 were teachers and the rest 10 were principal respondents and the questionnaire had properly filled in and returned with 147 in the total return rate of $98 \%$ and the response rate was ranged from $92.3 \%-100 \%$ in the sampled schools which was very scared to represent the views of the target population and the following Table 2 precisely showed the response rate of 10 sampled government secondary schools.

Table 2, we can see that in Kotergedera 17 questionnaire were distributed and all of them were properly filled and returned with the return rate of $100 \%$, in Agena 9 questionnaires were distributed and all of them were properly filled and returned with the return rate of 100\%, in Yewahny 17 questionnaires were distributed and 16 of them were filled and returned with the return rate of $94.1 \%$, in Aklile 13 questionnaires were distributed and all of them were properly filled and returned with the return rate of $100 \%$, in Teklehymanot 16 questionnaire were distributed and all of them were properly filled and returned with the return rate of 100\%, in Dakuna 19 questionnaire were distributed and 18 of them were filled and returned with the return rate of $94.7 \%$, in Gurda 17 questionnaire were distributed and all of them were properly filled and returned with the return rate of $100 \%$, in Gunchera 14 
questionnaires were distributed and all of them were properly filled and returned with the return rate of $100 \%$, in Gazanch15 questionnaire were distributed and all of them were properly filled and returned with the return rate of $100 \%$, in Holle 13 questionnaires were distributed and 12 of them were filled and returned with the return rate of $92.3 \%$. So the total return rate of the questionnaire was $147(98 \%)$. Whereas from each 10 sample secondary school students take 2298 as sample included in the study.

\section{Socio-Demographic Characteristics of study Respondents}

The characteristics of the study groups were examined in terms of sex, age, academic qualification of study and years of service.

\begin{tabular}{|c|c|c|c|c|c|c|}
\hline \multirow[t]{3}{*}{ No } & \multirow{3}{*}{ Variables } & \multirow{3}{*}{ Category } & \multicolumn{3}{|c|}{ Respondents } & \\
\hline & & & \multirow{2}{*}{$\begin{array}{l}\text { Teachers } \\
\text { Frequency }\end{array}$} & \multicolumn{3}{|c|}{ Principals } \\
\hline & & & & $\%$ & Frequency & $\%$ \\
\hline \multirow[t]{2}{*}{1.} & \multirow[t]{2}{*}{ Sex } & Male & 107 & $72.8 \%$ & 10 & $6.8 \%$ \\
\hline & & Female & 30 & $20.4 \%$ & 0 & 0 \\
\hline \multirow[t]{7}{*}{2.} & \multirow[t]{7}{*}{ Age } & $21-25$ & 38 & $25.9 \%$ & 3 & $2.0 \%$ \\
\hline & & $26-30$ & 54 & $36.7 \%$ & 3 & $2.0 \%$ \\
\hline & & $31-35$ & 13 & $8.8 \%$ & 2 & $1.4 \%$ \\
\hline & & $41-45$ & 19 & $12.9 \%$ & 1 & $0.7 \%$ \\
\hline & & $46-50$ & 6 & $4.1 \%$ & 1 & $0.7 \%$ \\
\hline & & $51-56$ & 3 & $2.0 \%$ & 0 & $0 \%$ \\
\hline & & 56 above & 4 & $2 . .7 \%$ & 0 & $0 \%$ \\
\hline \multirow[t]{3}{*}{3.} & \multirow{3}{*}{$\begin{array}{l}\text { Educational } \\
\text { qualification }\end{array}$} & Diploma & 5 & $3.4 \%$ & $0 \%$ & $0 \%$ \\
\hline & & $\mathrm{BA} / \mathrm{BSc} / \mathrm{BEd}$ & 127 & $86.4 \%$ & 9 & $6.1 \%$ \\
\hline & & $\mathrm{MA} / \mathrm{MSc}$ & 5 & $3.4 \%$ & 1 & $0.7 \%$ \\
\hline \multirow[t]{7}{*}{4.} & \multirow{7}{*}{$\begin{array}{l}\text { Work } \\
\text { experience }\end{array}$} & 5 and below & 31 & $21.1 \%$ & 1 & $0.7 \%$ \\
\hline & & 6-10 year & 42 & $26.8 \%$ & 4 & $2.7 \%$ \\
\hline & & $11-15$ year & 28 & $19.0 \%$ & 3 & $2.0 \%$ \\
\hline & & $16-20$ year & 11 & $7.5 \%$ & 1 & $0.7 \%$ \\
\hline & & 21-25years & 15 & $10.2 \%$ & 1 & $0.7 \%$ \\
\hline & & 26 and above & 10 & $6.8 \%$ & 0 & $0 \%$ \\
\hline & & Total & 137 & $93.2 \%$ & 10 & $6.8 \%$ \\
\hline
\end{tabular}

The two groups of respondents were asked to indicate their background information. The details of the responses were given in table 3 and discussed below.

As shown in (Table 3) Item 1, $107(72.8 \%)$ of teachers and $10(100 \%)$ of principals' were male respondents whereas, 30(20.4\%) teachers and none of the principals were female respondents. This shows that the majority of the respondents were males. This implies that the participation of females either in the secondary school teaching or involvement in the school leadership is too much less than males.

Regarding the age of respondents (Table 3) Item 2 shows, 38(25.9\%) of teacher respondents and $3(2.0 \%)$ of school principals respondents were between the age of 21-25 years. Others $54(36.7 \%)$ of teacher respondents and $3(2.0 \%)$ principals respondents fall between the ages of 26-30 years. In addition, $13(8.8 \%)$ of school teacher respondents and $2(1.4 \%)$ of principal respondents were between the ages of 31- 35 years. Besides, 19 (12.9\%) of teacher 
respondents and $1(0.7 \%)$ of school principals were between the age of 40-45 years. Moreover, $6(4.1 \%)$ of teacher respondents and $1(0.7 \%)$ of school leader respondents were between 46-50 years. And the remaining respondents $3(2.0 \%)$ teachers and none of the principals were between the ages of 51- 55 years. Finally, 4 (2.7\%) of teacher respondents and none of the principals were at the ages of 56 above years.

As far as educational qualification was concerned, $127(86.4 \%)$ of teacher respondents and $9(6.1 \%)$ of school leader respondents had a first degree of BA/BSC/BED. Whereas about 5 (3.4\%) teachers were diploma holders which is below the standard set for secondary schools. The last 5(3.4\%) teacher's respondents and 1(0.7\%) school principals had MA degree. Thus, that the majority of teachers' and school principals had first degree. From this, one can easily understand that, most of the respondents of the questionnaires and all interviewed head departments were subject area graduates; even though a blueprint of TDP (MoE, 2007) has stated that the academic qualification required for the secondary school principal is MA degree. Pristine and Thurston (1994) pointed out that the most popular measure of leader effectiveness is the extent to which the organization performs its tasks successfully and attains its goals.

Regarding work experience, $31(21.1 \%)$ teachers and 1(0.7\%) school principal's respondents had served below 5 years. while $42(26.8 \%)$ teachers and $4(2.7 \%)$ school principals had a service year between6-10. Twenty-eight (19.0\%) teachers and $3(2.0 \%)$ principals of respondents served between11-15 whereas $11(7.5 \%)$ and $1(0.7 \%)$ had 16-20 years of teaching experience and on the other hand, 15(10.2\%) teachers and principals $1(0.7 \%)$ respondents 21-25 work experience and the last 10 (6.8\%) above 26 years work experience. The work experience ranges indicate that most respondents were young and only a few were seniors. This implies that the majority of teacher respondents' were youngsters that help them to actively participate in school leadership effectiveness.

This statistical data and interview question responses reveal that school leaders were in opposition to today's school leadership qualities in experience, qualifications related to leadership. The leadership influence could be measured through their qualifications, the experience they have in leadership activity, their experience to delegate authorities and the provision of teachers' freedom to do their duties independently (Hoy \& Miskel, 2001).

\section{Results and Discussion of the Data}

Table 4: Extent of principal's leadership effectiveness in setting clear school vision.

The two groups of respondents were asked to rate the principals' leadership effectiveness on students' academic achievement. Accordingly, the responses of the teachers and leaders members were summarized in the following table and discussed below. 


\begin{tabular}{|c|c|c|c|c|c|c|}
\hline No & School leadership effectiveness to: & $\mathbf{R}$ & $\mathbf{N}$ & M & SD & $\mathbf{A M}$ \\
\hline \multirow{2}{*}{\multicolumn{2}{|c|}{$\begin{array}{l}\text { 1. Identify and include stakeholders in the process of developing a } \\
\text { shared vision }\end{array}$}} & $\mathbf{T}$ & $\begin{array}{ll}13 \\
7\end{array}$ & 3.5109 & .98606 & \multirow[t]{2}{*}{3.75} \\
\hline & & ScL & 10 & 4.0000 & .81650 & \\
\hline \multirow{2}{*}{\multicolumn{2}{|c|}{$\begin{array}{l}\text { 2. Articulate a vision focused on high levels of learning for all } \\
\text { students. }\end{array}$}} & $\mathbf{T}$ & $\begin{array}{l}13 \\
7\end{array}$ & 3.6058 & 1.01719 & \multirow[t]{2}{*}{3.65} \\
\hline & & ScL & 10 & 3.7000 & .82327 & \\
\hline & \multirow[t]{2}{*}{ 3. Implement a process for the development of a shared vision } & $\mathbf{T}$ & $\begin{array}{l}13 \\
7\end{array}$ & 3.4964 & .94809 & \multirow[t]{2}{*}{3.6} \\
\hline & & ScL & 10 & 3.6000 & 1.34990 & \\
\hline & \multirow{2}{*}{$\begin{array}{l}\text { 4. Identify goal areas that promote high levels of achievement for } \\
\text { all students and staff }\end{array}$} & $\mathbf{T}$ & $\begin{array}{l}13 \\
7\end{array}$ & 3.5109 & 1.03694 & \multirow[t]{2}{*}{3.7} \\
\hline & & ScL & 10 & 3.9000 & .99443 & \\
\hline & \multirow{2}{*}{$\begin{array}{l}\text { 5. Articulate well-defined beliefs about teaching and learning in } \\
\text { response to the environment and levels of student achievement }\end{array}$} & $\mathbf{T}$ & $\begin{array}{l}13 \\
7\end{array}$ & 3.5766 & .91332 & \multirow[t]{2}{*}{3.7} \\
\hline & & ScL & 10 & 3.9000 & .73786 & \\
\hline & \multirow{2}{*}{$\begin{array}{l}\text { 6. Establish clear and concrete strategic goals of the school with } \\
\text { participation of the staff }\end{array}$} & $\mathbf{T}$ & $\begin{array}{l}13 \\
7\end{array}$ & 3.4453 & 1.11751 & \multirow[t]{2}{*}{3.6} \\
\hline & & ScL & 10 & 3.8000 & 1.03280 & \\
\hline & \multirow{2}{*}{$\begin{array}{l}\text { 7. Formulate and demonstrate vision long range planning of the } \\
\text { school }\end{array}$} & $\mathbf{T}$ & $\begin{array}{l}13 \\
7\end{array}$ & 3.4964 & 1.00823 & \multirow[t]{2}{*}{3.6} \\
\hline & & ScL & 10 & 3.8000 & 1.03280 & \\
\hline \multirow{2}{*}{\multicolumn{2}{|c|}{$\begin{array}{l}\text { 8. Allocate resources for the proper implementation and } \\
\text { achievement of school vision and goals. }\end{array}$}} & $\mathbf{T}$ & $\begin{array}{l}13 \\
7\end{array}$ & 3.4307 & 1.03466 & \multirow[t]{2}{*}{3.6} \\
\hline & & ScL & 10 & 3.9000 & .99443 & \\
\hline \multirow{2}{*}{\multicolumn{2}{|c|}{$\begin{array}{l}\text { 9. Encouraged to develop action plans for improving our own } \\
\text { professional growth }\end{array}$}} & $\mathbf{T}$ & $\begin{array}{l}13 \\
7\end{array}$ & 3.3650 & 1.07701 & \multirow[t]{2}{*}{3.7} \\
\hline & & ScL & 10 & 4.1000 & .87560 & \\
\hline \multirow{2}{*}{\multicolumn{2}{|c|}{$\begin{array}{l}\text { 10. plan and work towards highest academic achievement of } \\
\text { students }\end{array}$}} & $\mathbf{T}$ & $\begin{array}{l}13 \\
7\end{array}$ & 3.5109 & 1.13835 & \multirow[t]{2}{*}{3.8} \\
\hline & & ScL & 10 & 4.2000 & .78881 & \\
\hline \multirow{2}{*}{\multicolumn{2}{|c|}{ 11. Frame the school goal for students' academic achievement }} & $\mathbf{T}$ & $\begin{array}{l}13 \\
7\end{array}$ & 3.5328 & 1.02219 & \multirow[t]{2}{*}{3.6} \\
\hline & & ScL & 10 & 3.8000 & .91894 & \\
\hline \multirow{2}{*}{\multicolumn{2}{|c|}{$\begin{array}{l}\text { 12. communicate the vision with stakeholders in order to have } \\
\text { common understanding and shared value }\end{array}$}} & $\mathbf{T}$ & $\begin{array}{l}13 \\
7\end{array}$ & 3.3650 & .99170 & \multirow{2}{*}{3.5} \\
\hline & & ScL & 10 & 3.8000 & 1.03280 & \\
\hline \multirow{2}{*}{\multicolumn{2}{|c|}{$\mathbf{A M}$}} & $\mathbf{T}$ & $\begin{array}{l}13 \\
7\end{array}$ & 3.48 & & \multirow[t]{2}{*}{3.65} \\
\hline & & ScL & 10 & 3.87 & & \\
\hline \multicolumn{7}{|c|}{ Source: Research Data, 2019} \\
\hline \multicolumn{7}{|c|}{$\begin{array}{l}\text { Key: } \text { Mean value } \geq 4.50=\text { very high, } 3.50-4.49=\text { high, } 2.50-3.49=\text { moderate, } 1.50-2.49=\text { low and } \\
\leq 1.49=\text { very low }\end{array}$} \\
\hline \multicolumn{7}{|c|}{$T=$ teachers $; \quad S C L=$ school principals } \\
\hline
\end{tabular}

The above table shows the functions and roles of school leaders to identify and include Stakeholders in the process of developing a shared vision. With regard to Item 1 of (Table 4), which is concerned with leaders' effectiveness to identify and include stakeholders in the process of developing a shared vision for the improvement of students' academic achievement, the mean value 3.51 and 4 were obtained from both teachers and leaders responses with 3.75 average mean score with $(\mathrm{SD}=98606 ; .81650)$ respectively. Identify and 
include stakeholders in the process of developing a shared vision is rated high performance when computing with the mean set as separation.

With regard to Item 2 of (Table 4), which is concerned with leaders' effectiveness in articulating school Vision goals and objectives for the improvement of students' academic achievement, the mean value 3.60 and 3.70 was obtained from both teachers and leaders responses with 3.65 average mean score with $(\mathrm{SD}=1.01719 ; .82327)$ respectively. Articulating school Vision goals and objectives for the improvement of students' academic achievement is rated high performance when computing with the mean set as demarcation. Schools need the participation of concerned stakeholders in the school plan (strategic and annual plan), but most of the time school plan is prepared by school principals. Therefore, the school mission and vision are not clear to all stakeholders and the intended students' outcome and ethical-centered activities are not achieved without the participation of stakeholders (MoE, 2007).

Regarding Item 3 of (Table 4), which is concerned to implement a process for the development of a shared vision the mean value 3.49 and 3.60 was obtained from both teachers and leaders responses with 3.6 average mean score with $(\mathrm{SD}=.94809 ; 1.34990)$ respectively. Implement a process for the development of a shared vision for the improvement of students' academic achievement is rated high performance when computing with the mean set as demarcation. With regard to this item, the interviewed head departments responded that they were involving the concerned stakeholders even though the data obtained from the questionnaire proofed it. In relation to this, Murphy (1990) stated that envisioning is a force that provides purpose, meaning and significance to the school improvement and creates commitment for the staff that contributes to the realization of the goals. At the school levels vision must be well articulated to all stakeholders' staff, students and parents.

Concerning Item 4 of (Table 4), Identify goal areas that promote high levels of achievement for all students and staff, the mean value 3.51 and 3.90 was obtained from both teachers and leaders' responses with 3.7 average mean score with $(\mathrm{SD}=1.03694 ; .99443$ ) respectively. Identify goal areas that promote high levels of achievement for all students and staff for the improvement of students' academic achievement is rated high performance when computing with the mean set as demarcation. According to interviewed head department report, most principals facilitate monthly staff meetings for teachers mainly focusing on instructional issues such as continuous assessment procedures, tutorial and makeup classes. They leave the school leadership activities for the department heads, principals and the teachers themselves.

With respect to Item 5 of (Table 4), Articulate well-defined beliefs about teaching and learning in response to the environment and levels of student achievement the mean value 3.57 and 3.90 was obtained from both teachers and leaders responses with 3.7 average mean score with $(. \mathrm{SD}=.91332 ; .73786)$ respectively. Articulate well-defined beliefs about teaching and learning in response to the environment and levels of student achievement for the 
improvement of students' academic achievement is rated high performance when computing with the mean set as a high point of 5 .

With regard to Item 6 of (Table 4), respondents were requested to rate establish clear and concrete strategic goals of the school with the participation of the staff the mean value 3.44 and 3.80 was obtained from both teachers and leaders responses with 3.6 average mean score with $(\mathrm{SD}=1.11751 ; 1.03280)$ respectively. Establish clear and concrete strategic goals of the school with the participation of the staff for the improvement of students' academic achievement is rated high performance when computing with the mean set as high level.

With respect to Item 7 of (Table 4), the respondents were requested to rate the formulated vision of the school. The mean value 3.49 and 3.80 was obtained from both teachers and leaders responses with a 3.6 average mean score ( $\mathrm{SD}=1.00823 ; 1.03280$ ) respectively. Formulate and demonstrate vision long-term planning of the school for the improvement of students' academic achievement is rated high performance when computing with the mean set as separation.

With Item 8 of (Table 4), the respondents were requested to rate concerning the allocation of resources for the proper implementation and achievement of school vision and goals the mean value 3.43 and 3.90 was obtained from both teachers and leaders responses with 3.6 average mean score with $(\mathrm{SD}=1.03466 ; .99443)$ respectively. The allocation of resources for the proper implementation and achievement of school vision and goals for the improvement of students' academic achievement is rated high performance when computing with the mean set as demarcation. On the other hand, all the interviewed head departments raised a lack of educational resources and lack of training concerning leadership as one factor for the ineffectiveness of their leadership on students' academic achievement.

With Item 9 of (Table 4), the respondents were requested to rate concerning the encouragement to develop action plans for improving their professional growth the mean value 3.36 and 4.10 was obtained from both teachers and leaders responses with a 3.7 average mean score with $(\mathrm{SD}=1.07701 ; .87560)$ respectively. The encouraged to develop action plans for improving their professional growth for the improvement of students' academic achievement is rated high performance when computing with the mean set as demarcation.

With regard to assessing plan and work towards the highest academic achievement of students, Item 10 of (Table 4), the mean value 3.51 and 4.20 were obtained from both teachers and leaders' responses with 3.8 average mean score with $(\mathrm{SD}=1.13835 ; .78881)$ respectively. Assessing plan and work towards the highest academic achievement of students for the improvement of students' academic achievement is rated high performance when computing with the mean set as demarcation.

With regard to frame the school goal for students' academic achievement, Item 11 of (Table 4), the mean value 3.53 and 3.80 was obtained from both teachers' and leaders' responses with 3.6 average mean score with $(\mathrm{SD}=1.02219 ; .91894)$ respectively. Frame the school goal 
for students' academic achievement for the improvement of students' academic achievement is rated high performance when computing with the mean set as high level. The interviewed head department responded that they spend most of their time conducting different capacity building, meeting, resolving conflicts made both between teachers and students and among students in the schools. Concerning communicating the vision with stakeholders to have a common understanding and shared value Item 12 of (Table 4), the mean value 3.36 and 3.80 was obtained from both teachers and leaders responses with 3.5 average mean score with (SD $=.99170 ; 1.03280$ ) respectively. Communicating the vision with stakeholders to have a common understanding and shared value for the improvement of students' academic achievement is rated high performance when computing with the mean set as demarcation.

Generally, the school leadership effectiveness in working with the school vision, mission, and goals is rated as highly effective because the overall average mean score obtained from the table was 3.65and the document analysis made also shows that there is no problem.

Table 5: The school principal effectiveness promotes professional practice to enhance students' academic achievement.

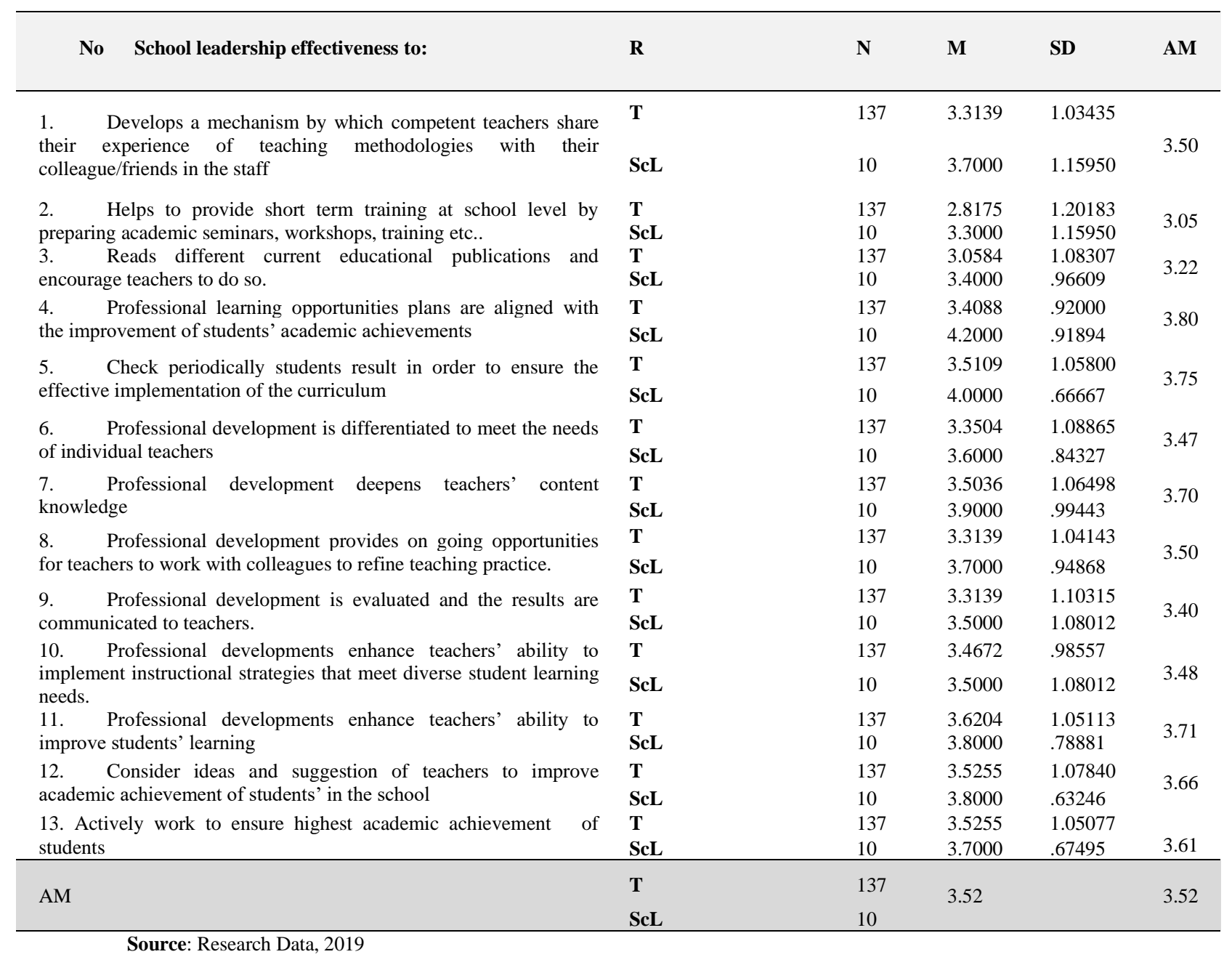

Key: Mean value $\geq 4.50=$ very high, $3.50-4.49=$ high, $2.50-3.49=$ moderate, $1.50-2.49=$ low and $\leq 1.49=$ very low

$\mathrm{T}=$ teachers; $\mathrm{SCL}=$ school principals 
With regard to (Table 5), Item 1 to Develops a mechanism by which competent teachers share their experience of teaching methodologies with their colleague/friends in the staff, item 1 of Table 5, the mean value 3.31 and 3.70 was obtained from both teachers and leaders responses with 3.50 average mean score with $(\mathrm{SD}=1.03435 ; 1.15950)$ respectively. Frame Develops a mechanism by which competent teachers share their experience of teaching methodologies with their colleagues/friends in the staff is rated high performance when computing with the mean set as demarcation.

With regard to Helps to provide short term training at the school level by preparing academic seminars, workshops, training, Item 2 of (Table 5), the mean value 2.81 and 3.30 was obtained from both teachers and leaders responses with a 3.05 average mean score with (SD $=1.03435 ; 1.15950)$ respectively. The frame helps to provide short-term training at the school level by preparing academic seminars, workshops, training is rated high performance when computing with the mean set as demarcation. With regard to reading different current educational publications and encouraging teachers to do so, Item 3 of (Table 5), the mean value 3.05 and 3.40 were obtained from both teachers and leaders' responses with a 3.22 average mean score with ( $\mathrm{SD}=1.08307$; .96609) respectively. Reads different current educational publications and encourages teachers to do so the rated high performance when computing with the mean set as out of a maximum of 5 .

Concerning Item 4 of (Table 5), with regards to professional learning opportunities plans are aligned with the improvement of students' academic achievements, the mean value 3.40 and 3.40 was obtained from both teachers' and leaders' responses with a 3.80 average mean score with $(. S D=(92000 ; .91894)$ respectively. Professional learning opportunities plans are aligned with the improvement of students' academic achievements are rated high performance when computing with the mean set as out of a maximum of 5 . The information obtained from the interviews confirmed that the leaders could not well prepare plans that show for the highest academic achievement of the students in schools where the study was conducted except for two of the sample schools.

With Item 5 of (Table 5), regards to check periodically students result to ensure the effective implementation of the curriculum the mean value 3.51 and 4.00 was obtained from both teachers and leaders responses with 3.75 average mean score with ( $\mathrm{SD}=1.05800 ; .66667$ ) respectively. To check periodically students' results to ensure the effective implementation of the curriculum is rated high performance when computing with the mean set as demarcation. With Item 6 of (Table 5), the respondents were requested to rate concerning Professional development is differentiated to meet the needs of individual teachers the mean value 3.35 and 3.60 was obtained from both teachers and leaders responses with a 3.47 average mean score with $(\mathrm{SD}=1.08865 ; .84327)$ respectively. The Professional development is differentiated to meet the needs of individual teachers is rated high performance when computing with the mean set as demarcation.

With regards to Professional development deepens teachers' content knowledge, Item 7 of (Table 5), the mean value 3.50 and 3.90 was obtained from both teachers and leaders' 
responses with a 3.70 average mean score with $(\mathrm{SD}=1.06498$; .99443$)$ respectively. Professional development deepens teachers' content knowledge is rated high performance when computing with the mean set as out of a maximum of 5 .

With regards to Professional development provides ongoing opportunities for teachers to work with colleagues to refine teaching practice, Item 8 of (Table 5), the mean value 3.31 and 3.70 was obtained from both teachers and leaders responses with 3.50 average mean score with ( $\mathrm{SD}=1.04143 ; .94868$ ) respectively. Professional development provides an ongoing opportunity for teachers to work with colleagues to refine teaching practice is rated high performance when computing with the mean set as demarcation. Regarding Item 9 of (Table 5), the respondents rated Professional development is evaluated and the results are communicated to teachers, the mean value 3.31 and 3.50 was obtained from both teachers and leaders responses with 3.40 average mean score with $(\mathrm{SD}=1.10315 ; 1.08012$ ) respectively. Professional development is evaluated and the results are communicated to teachers is rated high performance when computing with the mean set as demarcation.

With regard to Item 10 of (Table 5), the respondents rated to Professional developments enhance teachers' ability to implement instructional strategies that meet diverse student learning needs, the mean value 3.46 and 3.50 was obtained from both teachers and leaders responses with 3.48 average mean score with $(\mathrm{SD}=.98557 ; 1.08012)$ respectively. Professional developments enhance teachers' ability to implement instructional strategies that meet diverse student learning needs are rated high performance when computing with the mean set as demarcation. Regarding Item 11 of (Table 5), the respondents rated Professional developments enhance teachers' ability to improve students' learning, the mean value 3.62 and 3.80 was obtained from both teachers and leaders' responses with 3.71 average mean score with $(\mathrm{SD}=1.05113 ; .78881)$ respectively. Professional developments enhance teachers' ability to improve students' learning is rated high performance when computing with the mean set as a demarcation

With regard to Item 12 of (Table 5), the respondents rated Considering the ideas and suggestion of teachers to improve the academic achievement of students in the school the results showed that the mean value 3.52 and 3.80 was obtained from both teachers and leaders responses with 3.66 average mean score with $(\mathrm{SD}=1.7840 ; .63246)$ respectively. Considering the ideas and suggestions of teachers to improve the academic achievement of students in the school is rated high performance when computing with the mean set as demarcation. From the responses to Item 13 of (Table 5), which relates to actively work to ensure the highest academic achievement of students, the mean value 3.52 and 3.70 was obtained from both teachers and leaders responses with a 3.61 average mean score with $(\mathrm{SD}=1.05077 ; .67495)$ respectively. Actively work to ensure the highest academic achievement of students is rated high performance when computing with the mean set as demarcation.

In summary, School principal effectiveness to promote professional practice and enhance students' academic achievement is rated as highly effective because the overall average mean 
score obtained from the table was 3.52and the document analysis made also shows that there is no problem.

Table 6: School principal effectiveness for teachers as a leader to enhance students' academic achievements in secondary school at Guraghe zone

\begin{tabular}{|c|c|c|c|c|c|}
\hline No School leadership effectiveness to: & $\mathbf{R}$ & $\mathbf{N}$ & MA & SD & $\mathbf{A M}$ \\
\hline \multirow{2}{*}{$\begin{array}{l}\text { Coordinate the curriculum evaluation process of the school to } \\
\text { address problems related to the curriculum. }\end{array}$} & $\mathrm{T}$ & 137 & 3.4088 & .93584 & \multirow{2}{*}{3.65} \\
\hline & $\mathrm{ScL}$ & 10 & 3.9000 & .73786 & \\
\hline \multirow{2}{*}{$\begin{array}{l}\text { 2. Advice teachers and department heads regarding the challenges } \\
\text { they faced in relation to the implementation of the curriculum }\end{array}$} & $\mathrm{T}$ & 137 & 3.5912 & .99672 & \multirow{2}{*}{3.89} \\
\hline & $\mathrm{ScL}$ & 10 & 4.2000 & .78881 & \\
\hline \multirow{2}{*}{$\begin{array}{l}\text { 3. Ensure the timely allocation of resources (human, material and } \\
\text { financial) necessary for instructional process }\end{array}$} & $\mathrm{T}$ & 137 & 3.285 & 1.0843 & \multirow[t]{2}{*}{3.59} \\
\hline & $\mathrm{ScL}$ & 10 & 3.900 & .8756 & \\
\hline \multirow{2}{*}{$\begin{array}{l}\text { 4. Check periodically students result in order to ensure the effective } \\
\text { implementation of the curriculum }\end{array}$} & $\mathrm{T}$ & 137 & 3.5839 & .95211 & \multirow[t]{2}{*}{3.94} \\
\hline & $\mathrm{ScL}$ & 10 & 4.3000 & .48305 & \\
\hline \multirow{2}{*}{$\begin{array}{l}\text { 5. provide adequate school facilities that enable to facilitate the } \\
\text { teaching learning process }\end{array}$} & $\mathrm{T}$ & 137 & 3.4307 & .91391 & \multirow{2}{*}{3.46} \\
\hline & $\mathrm{ScL}$ & 10 & 3.5000 & 1.08012 & \\
\hline \multirow{2}{*}{$\begin{array}{l}\text { 6. Continuously assist and give constructive feedbacks that improves } \\
\text { teachers performance in teaching }\end{array}$} & $\mathrm{T}$ & 137 & 3.4599 & 1.05031 & \multirow[t]{2}{*}{3.62} \\
\hline & $\mathrm{ScL}$ & 10 & 3.8000 & .78881 & \\
\hline \multirow{2}{*}{$\begin{array}{l}\text { 7. Encouraging staff attendance at workshop, seminar and } \\
\text { conference to update them on current issues }\end{array}$} & $\mathrm{T}$ & 137 & 3.3285 & 1.15752 & \multirow[t]{2}{*}{3.66} \\
\hline & $\mathrm{ScL}$ & 10 & 4.0000 & .81650 & \\
\hline \multirow{2}{*}{$\begin{array}{l}\text { 8. Consider ideas and suggestion of teachers to improve academic } \\
\text { achievement of students' in the school }\end{array}$} & $\mathrm{T}$ & 137 & 3.5328 & 1.09175 & \multirow[t]{2}{*}{3.81} \\
\hline & $\mathrm{ScL}$ & 10 & 4.1000 & .73786 & \\
\hline \multirow{2}{*}{$\begin{array}{l}\text { 9. Encourage internal supervision to enhance the teaching learning } \\
\text { process. }\end{array}$} & $\mathrm{T}$ & 137 & 3.4234 & 1.10295 & \multirow{2}{*}{3.56} \\
\hline & $\mathrm{ScL}$ & 10 & 3.7000 & 1.05935 & \\
\hline \multirow{3}{*}{$\begin{array}{l}\text { 10. Make sure that teachers are providing leader support for students } \\
\text { based on their learning styles or abilities. }\end{array}$} & $\mathrm{T}$ & 137 & 3.6131 & 1.00914 & \multirow{3}{*}{3.85} \\
\hline & & & & & \\
\hline & $\mathrm{ScL}$ & 10 & 4.1000 & .87560 & \\
\hline \multirow{2}{*}{$\mathrm{AM}$} & $\mathrm{T}$ & 137 & 3.46 & & \multirow[b]{2}{*}{3.70} \\
\hline & $\mathrm{ScL}$ & 10 & 3.95 & & \\
\hline
\end{tabular}

Source: Research Data (2019)

Key: Mean value $\geq 4.50=$ very high, 3.50-4.49= high, 2.50-3.49= moderate, $1.50-2.49=$ low and $\leq 1.49=$ very low

$T=$ teachers $; \quad S C L=$ school principals

According to the data obtained from the two groups on Item 1 of (Table 6), which relates to that coordinate the curriculum evaluation process of the school to address problems related to the curriculum, the mean value 3.40 and 3.90 was obtained from both teachers and leaders responses with 3.65 average mean score with $(\mathrm{SD}=.93584 ; .73786)$ respectively. Coordinate the curriculum evaluation process of the school to address problems related to the curriculum is rated high performance when computing with the mean set as demarcation. 
From the responses to Item 2 of (Table 6), which relates to the degree of perception on whether Advice teachers and department heads regarding the challenges they faced in relation to the implementation of the curriculum, the mean value 3.59 and 4.20 was obtained from both teachers and leaders responses with 3.89 average mean score with $(\mathrm{SD}=.99672 ; .78881)$ respectively. Degree of perception on whether advice teachers and department heads regarding the challenges they faced in relation to the implementation of the curriculum is rated high performance when computing with the mean set as demarcation. Regarding from the responses to Item 3 of (Table 6), Respondents rated to ensure the timely allocation of resources (human, material and financial) necessary for the instructional process, the mean value 3.2 and 3.90 was obtained from both teachers and leaders responses with 3.59 average mean score with $(\mathrm{SD}=1.0843 ; .8756)$ respectively. Ensure the timely allocation of resources (human, material and financial) necessary for the instructional process is rated high performance when computing with the mean set as demarcation. Moreover, school leaders for the proper implementation and achievement of school vision and goals are rated as highperformance level.

Regarding Item 4 of (Table 6), Respondents rated to check periodically students result to ensure the effective implementation of the curriculum, the mean value 3.58 and 4.30 was obtained from both teachers and leaders responses with a 3.94 average mean score with (SD $=.95211 ; .48305)$ respectively. Check periodically students result to ensure the effective implementation of the curriculum is rated high performance when computing with the mean set as demarcation. Regarding Item 5 of (Table 6), Respondents rated to provide adequate school facilities that enable to facilitate the teaching-learning process, the mean value 3.43 and 3.50 was obtained from both teachers and leaders responses with 3.46 average mean score with $(\mathrm{SD}=.91391 ; 1.08012)$ respectively. Provide adequate school facilities that enable to facilitate the teaching-learning process is rated high performance when computing with the mean set as demarcation.

Regarding Item 6 of (Table 6), Respondents rated, Continuously assist and give constructive feedback that improves teachers performance in teaching, the mean value 3.45 and 3.80 was obtained from both teachers and leaders responses with a 3.62 average mean score with $(\mathrm{SD}=$ $1.05031 ; .78881)$ respectively. Continuously assist and give constructive feedbacks that improve teachers' performance in teaching is rated high performance when computing with the mean set as demarcation.

Regarding the responses to Item 7 of (Table 6), Respondents rated encouraging staff attendance at workshop, seminar, and conference to update them on current issues, the mean value 3.32 and 4.00 was obtained from both teachers and leaders responses with a 3.66 average mean score with $(\mathrm{SD}=1.15752 ; .81650)$ respectively. Encouraging staff attendance at workshops, seminars, and conferences to update them on current issues is rated high performance when computing with the mean set as demarcation. One can understand that the encouragement of staff attendance or presence at workshops, seminars, and conferences by school leaders is rated Moderate. The interviewed head departments revealed that few organized in-service training programs can build their leadership capacity in the area of both 
instructional and administrative school activities, but sometimes the meeting was at the end of the year at woreda level.

Concerning Item 8 of (Table 6), the respondents rated consider ideas and suggestion of teachers to improve the academic achievement of students in the school, the mean value 3.53 and 4.10 was obtained from both teachers and leaders responses with a 3.81 average mean score with $(\mathrm{SD}=1.09175 ; .73786)$ respectively. Consider ideas and suggestions of teachers to improve the academic achievement of students in the school is rated high performance when computing with the mean set as demarcation. Regarding Item 9 of (Table 6), the respondents rated encourage internal supervision to enhance the teaching-learning process, the mean value 3.42 and 3.70 was obtained from both teachers and leaders' responses with 3.56 average mean score with $(\mathrm{SD}=1.10295 ; 1.05935)$ respectively. Encourage internal supervision to enhance the teaching-learning process is rated high performance when computing with the mean set as demarcation.

Concerning Item 10 of (Table 6), the respondents rated to make sure that teachers are providing leader support for students based on their learning styles or abilities. The analyzed mean values were 3.61 and 4.10 were obtained from both teachers' and leaders' responses with a 3.85 average mean score with $(\mathrm{SD}=1.00914 ; .87560)$ respectively. Make sure that teachers are providing leader support for students based on their learning styles or abilities is rated high performance when computing with the mean set as a demarcation

Generally, as it was discussed clearly on the above from most of the School principal effectiveness for teachers as a leader to enhance students' academic achievements in secondary school at Guraghe zone is rated as highly effective because the overall average mean score obtained from the table was 3.70and the document analysis made also shows that there is no problem.

Table 7: Proportion of Grade ten students who passed national examination CGPA) in their respective schools from $2009-2010$ in all subjects (10)

\begin{tabular}{|c|c|c|c|c|c|c|c|c|c|c|}
\hline \multirow[b]{2}{*}{ No } & \multirow[b]{2}{*}{ Schools } & \multicolumn{3}{|l|}{2009} & \multicolumn{3}{|l|}{2010} & \multicolumn{3}{|l|}{ Total } \\
\hline & & $\mathbf{N}$ & $\mathbf{N}$ & $\%$ & $\mathbf{N}$ & $\mathbf{N}$ & $\%$ & $\mathbf{N}$ & $\mathbf{n}$ & $\%$ \\
\hline 1. & Kotergedera & 285 & 150 & 52.6 & 220 & 128 & 54.5 & 505 & 278 & $55 \%$ \\
\hline 2. & Agena & 98 & 55 & 56.1 & 120 & 63 & 52.5 & 218 & 118 & $54.1 \%$ \\
\hline 3. & Yewahny & 372 & 145 & 38.9 & 240 & 102 & 42.5 & 612 & 247 & $40.3 \%$ \\
\hline 4. & Aklile & 387 & 140 & 36.1 & 315 & 114 & 36.1 & 702 & 254 & $36.1 \%$ \\
\hline 5. & Teklehymanot & 423 & 150 & 35.4 & 365 & 215 & 58.9 & 788 & 420 & $53.2 \%$ \\
\hline 6. & Dakuna & 529 & 240 & 45.3 & 350 & 130 & 37.1 & 879 & 470 & $53.4 \%$ \\
\hline 7. & Gurda & 138 & 65 & 47.1 & 125 & 52 & 41.6 & 263 & 117 & $44.4 \%$ \\
\hline 8. & Gunchera & 240 & 105 & 43.75 & 185 & 94 & 50.8 & 425 & 199 & $46.8 \%$ \\
\hline 9. & Gazanch & 80 & 35 & 43.75 & 110 & 50 & 45.4 & 190 & 85 & 44.75 \\
\hline 10. & Holle & 120 & 50 & 41.6 & 134 & 60 & 44.7 & 254 & 110 & $44.8 \%$ \\
\hline & & 2672 & 1135 & 44.06 & 2164 & 1008 & 46.4 & 4836 & 2298 & $47.5 \%$ \\
\hline
\end{tabular}


$\mathrm{M}=$ Mean result, $\mathrm{N}=$ Total number of students who took grade ten national examinations in the specified year in each school, $\mathrm{n}=$ Total number of students who took grade ten national examinations in the specified year and who scored CGPA $=($ Cumulative grade point average $)>2$ in each school.

As it was obtained in (Table7), among the sampled secondary schools students who took grade ten national examinations in 2009E.C, 2010E.C., and 2010E.C relatively, the highest percentage of students who scored mean passing CGPA was recorded Kotergedera $(54.5 \%)$, Agena (52.5\%), Teklehymanot(58.9\%), and Gunchera(50.8\%) respectively passed the rest not passed. When the recorded mean cumulative grade point average (CGPA) of students each of the sampled schools was considered in each year (2009 and 2010 E.C.), there are four secondary schools namely Kotergedera, Agena, Teklehymanot, and Gunchera secondary school students were able of achieving passing mean CGPA the rest six secondary school does not achieve the results.

Generally, students' academic achievement is rated as 'low'. In addition, the interviewed head departments also confirmed that the students' academic achievement was 'very low'. In addition to that, the documents observed show that the academic achievement of students is found to be below the benchmark set by the schools. The document analyzed in the sample schools shows the result of students on the national examinations is very low especially promotion of students from grade 10 to grade 11 is very poor. From 2010, only $46.4 \%$ of students scored a promotion result for preparatory and $46.4 \%$ scored 2:00 and above while the remaining $53.6 \%$ of the students scored below 2:00 (average) in the sampled secondary schools of the study area. This implies that the students' achievement was rated as a very poor performance.

\section{The Correlation Matrix Results}

Table 8.The relationship between school Leadership effectiveness and Students' Academic Achievement (A matrix of Correlations)

\begin{tabular}{llll}
\hline & & Academic achievement & School Leadership effectiveness \\
\hline \multirow{3}{*}{ Academic achievement } & Pearson Correlation & 1 & $.653^{*}$ \\
& Sig. (2-tailed) & & .041 \\
& $\mathrm{~N}$ & 147 & 147 \\
& Pearson Correlation & $.653^{*}$ & .041 \\
& Sig. (2-tailed) & 147 & 147 \\
\hline
\end{tabular}

*. Correlation is significant at the 0.05 level (2-tailed).

To see the relationship between school Leadership effectiveness and Students' Academic correlation analysis was carried out; specifically, Person's Correlations coefficients test was calculated to find the relationships between the two variables. The leadership effectiveness mean score of each three table shows and students' academic achievement overall Selected 10 secondary school of Guraghe zone mean cumulative grade point average (CGPA) of students in table 7 were correlated used the Pearson's Correlation. This gave a correlation coefficient (r) which showed the direction of association between the variables as summarized in Table 8 Pearson's Correlation Coefficient was used to establish the relationship between school Leadership effectiveness and students' academic achievement. 
There was a positive relationship between Leadership effectiveness and students' academic achievement ( $\left.\mathrm{r}=.653^{*}, \mathrm{n}=147, \mathrm{p}<.0 .041\right)$. In general, dependent variables like; students' academic achievement $\left(\mathrm{r}=0.653^{*} \mathrm{p}<0.041\right)$; independently had a moderately positive correlation with school leadership effectiveness. This implies that when leadership dimensions are well managed academic achievement is highly improved. These results also agreed with the theoretical base with ones (eg. Tschannen-Moran, 2004; Lapidot, Kark\& Shamir, 2007, Hoy\&Tschannen-Moran, 2003; Field, 2008). The relationship between school leadership effectiveness and student achievement was that the principals were able to create a shared vision that focused on high achievement and overall school goals. The findings suggested that school principal's effectiveness in the study may have recognized the need to work hard in order to boost achievement among the students.

\section{Conclusion and Suggestion}

Regarding the extent of the principal's leadership effectiveness in setting clear school vision and raising students' academic achievements in all the sampled secondary schools and at the zonal level, the overall average mean score obtained from the table was 3.65for each role of the school principals and entirely was moderate. This indicates that effectiveness was sufficient but the existence of obstacles limited the performance of principals in each sampled secondary school. There was an association with a significant relationship that existed between school leadership effectiveness and students' academic achievement.

To improve learning and students' achievement, the focus should be on the development of qualified and experienced teachers with strong school leadership effectiveness abilities. The teachers can also be encouraged and provided with financial support to attend professional development programs (CPD), seminars and conferences. School administration should also create an environment conducive to the growth of principal's leadership effectiveness. Teachers should be encouraged to continuously acquire leadership skills within and outside school systems through training, workshops, and seminars. Moreover, most of the items used to measure the extent of the roles of principals for the four main variables showed that there were significant differences in the mean response of the respondents for the sampled secondary schools. The number of students who promoted the grade ten national examinations was insignificant compared to the number of students who took the examinations in the indicated years. This also indicated the existence of various contributing challenges in the sampled secondary schools and woredas. As the study revealed that, the correlation of school principals' effectiveness was positive, but students' grade ten national examinations weak. In general, in the sampled secondary schools the performance of the secondary school principals in setting and clear school vision, promoting professional development, and providing support for teachers was inadequate and showed the presence of various factors hindering higher performance. Thus, more attention is necessary to solve the problems to positively influence students' success.

Furthermore, the two years (2009-2010E.C.) mean CGPA of the sample secondary schools students at the zonal level indicated inconsistent results among the years and the results were 
inadequate and small. Moreover, it could be concluded that there was a gap in the school leadership effectiveness to contribute to students' academic achievement in the secondary schools of Guraghe zone. The study found out that students' academic achievement is a direct function of principals' leadership effectiveness. This implies that there is a direct relationship between school leadership and students' academic achievement. Leadership may directly affect students' academic achievement through improving school vision and school goals.

Based on the findings, for the success to the effectiveness of school leadership on students' academic achievement, the school leaders are advised to do their best in setting a good school vision, mission and goals to improve their student's achievement teachers and concerned stakeholders in secondary schools. From the results of the study, the researchers recommend that effective school leadership should be improved by introducing leadership training sessions in schools. Woreda Education Office and the school leaders are advised to create awareness to provide teachers with current information and update them for the better academic achievement of the students in the school. Almost all principals who were leading the sampled schools were subject specialists who had not attended any training to strengthen their school leadership effectiveness. Therefore, the researcher strongly recommends Regional Education Bureau and Zone Education Office provide leadership trainings for school leaders as an in-service program or in any possible ways to fill the gap and capacitate the school leaders.

Although this research may have its contribution in understanding the effectiveness of school leadership on students' academic achievements in Guraghe Zone, the outcomes of the study were not completed as was initially anticipated. Therefore, the researcher recommends that those who want to conduct further study on the effectiveness of school leadership on academic achievement of students in the secondary schools of the zone. Secondary school principals need to have strong commitment and work hard cooperatively with school communities to help their students to achieve higher results in their academic and to be competent in all aspects of their future life. Secondary school principals need to clearly communicate the school vision with all concerned school communities by avoiding the perceived negative perceptions and work together to achieve it as a common destination point for the school communities by creating a conducive situation. On top of that, school principals are strongly recommended to undertake a strategic visioning whereby the leaders and the stakeholders create a vision for the school. Finally, the study recommended that school principals should strengthen the relation of the school with stakeholders to accomplish tasks collaboratively and to achieve students' academic results.

\section{Conflict of Interest}

The authors of the article declare no conflict of interest.

\section{Funding}

The costs of conducting the study and for publishing this article are of the authors. 


\section{References}

Aklilu Alemu (2011). An Assessment of Instructional Leadership Practice in the Secondar Schools of Sheka Zone. (MA Thesis) Addis Ababa University

Abiy Zegeye, et.al (2009). Introduction to research methods. Graduate studies and research office: Addis Ababa University

Bakhda, S. (2006). Management and Evaluation of Schools. Nairobi: Oxford University.

Buhere, P., (2007). A study of Quality of Education in Public Secondary Schools in Bungoma Division of Bungoma District. (Unpublished MED Project), University of Nairobi..

Bush, T. (2007). Educational leadership and management: Theory, policy and practice. South African journal of education, 27(3), 391-406.

Creswell, J. W. (2012). Educational research: Planning, conducting, and evaluating quantitative. Upper Saddle River, NJ: Prentice Hall.

Cuban, L. (1988), The Managerial Imperative and the Practice of Leadership in Schools. Albany, NY, State University of New York Press.

Conley, D. (2007). Towards a More Comprehensive Conception of College Readiness. Eugene: Educational Policy Improvement Center.

Daniel Sorato (2018), principal's leadership effectiveness in public secondary schools of kembata tembaro zone (SNNPR) (MA Thesis), Jimma University.

Drucker. (2011), Educational Leadership: Key Challenges and Ethical Tensions. New York: Cambridge University Press.

Firestone, W. A., \& Herriott, R. E. (1982). Prescriptions for effective elementary schools don't fit secondary schools. Educational Leadership, 40(3), 51-53.

Gay, L. R. (1992). Education Research Competencies for Analysis and Application: London: Charles E. Milton Keynes Philadelphia Company.

Grift, W. V. D. (1990). Educational leadership and academic achievement in elementary education. School Effectiveness and School Improvement, 1(1), 26-40.

Huber, S. G. (2004). Preparing school leaders for the 21 st century: an international comparison ofdevelopment programs in 15 countries. London: Taylor \& Francis Group.

Hoy, W. K., \& Tschannen-Moran, M. (2007). The conceptualization and measurement of faculty trust in schools. Essential ideas for the reform of American schools, 87-114.

Ibukun, W.O., Oyewole, B. K., \& Abe, T. O. (2011). Personality characteristics and Principal leadership effectiveness in Ekiti State, Nigeria. International Journal of Leadership Studies, 6(2), 248-262.

Kumar, R. (1999). Research mythology. London: SAGE Publications.

Leithwood.(2007). Changing leadership for changing times. Buckingham: Open University Press..

Leithwood, K. and Riehl, C. (2008). What we know about successful school leadership. Philadelphia: Laboratory for Student Success, Temple University.

Louis, K. S., Dretzke, B., \&Wahlstrom, K. (2010). How does leadership affect student achievement? 1 Results from a national US survey. School Effectiveness and School Improvement, 21 (3), 315-336. 
Matthews, P., \& Sammons, P. (2005). Survival of the weakest: The differential improvement of schools causing concern in England. London Review of Education, 3, 159-176.

Mequanint Shiferaw (2012: Principals Leadership style of Public Secondary schools of JimmaZone

MoE(1994).Education And Training Policy, Addis Ababa: Brehanena Selam Printing Enterprise.

MoE (2006), Educational management, organization, community participation and finance/ Amharic Version/ Addis Ababa: EMPDA

MOE. (2007). National professional Standard for School Principal. Addis Ababa: MOE.

MoE, (2010) The combination of these strategies is expected to lead to a significant improvement in student achievement.

Thakur, D.N. \& Thakur, D. (2004). Educational Planning and Administration

Murphy, J. (1990). Principal instructional leadership. Advances in educational administration: Changing perspectives on the school, 1(Part B), 163-200..

Oakland, E. (1993). Total Quality management: The Route to Improving Performance. London: Clays, St. Ivas Plc. review of empirical research, 1980-1995. Educational Administration Quarterly,32(1), 5-44.

Pont, B., Nusche, D. \& Moorman, H. (2008). Improving School Leadership Volume 1: Policy and Practice, Paris: Organization for Economic Cooperation and Development.

Wango, G. (2009). School Administration and Management. Nairobi: The Jomo Kenyatta

Yemane,T.(1967).Statistics, An Introductory Analysis.( 2nd ed.). New York: Harper and Row. 